\title{
The Causes of Loan Default in Microfinance Banks: The Experience of Standard Microfinance Bank, Yola, Adamawa State, Nigeria.
}

\author{
Asongo, A.I ${ }^{1}$, Adamu Idama ${ }^{1}$ \\ ${ }^{I}$ Department of Operations Research, \\ Moddibo Adama University of Technology (MAUTECH), Yola, Nigeria
}

\begin{abstract}
This study was conducted to determine the causes of loan default in microfinance Banks, the experience of Standard Microfinance Bank Limited, Yola, Nigeria. One Hundred and Sixty Nine questionnaires were administered to the customers and twenty questionnaires administered to the staff of the Bank respectively. All the questionnaires were completed and returned. The data was analyzed using Statistical Package for Social Sciences (SPSS Version Twenty One). Descriptive and inferential statistics such as tables, frequency distributions and percentages were generated. It was discovered that the causes of loan default in microfinance banks are numerous including but not limited to High staff turnover and clients dropouts, non-supervision of some customers on their loan funds utilization, non-reminder of some customers concerning their repayment, multiple borrowings by the customers, lack of penalty to some defaulters, lack of job experience by the staff and lack of full compliance to lending policies by the staff. Based on the findings of this study, relevant recommendations were made to Microfinance Banks to ensure industry best practices and optimum performance.
\end{abstract}

Keywords: Delinquency, Customers, Loan default, Microfinance Banks,

\section{Introduction}

According to Central Bank of Nigeria (2011), Microfinance Banks in Nigeria have been confronted by numerous challenges since the launch of the Microfinance policy framework in December, 2005. The impact of the global financial crisis of 2007/2008 on Microfinance Banks was more severe than anticipated. Credit lines dried up, competition became more intense and credit risk increased to the extent that many clients of Microfinance Banks (MFBs) were unable to pay back their loans owing to the hostile economic environment.

Nnanna (2003) said, over the years, the banking industry has witnessed periodic bank distress and sometimes failures. The problem of bank distress has been traced to a number of factors, prominent among which is improper risk management, others are non-compliance to the monitory and regulatory authorities, economic factors etc.

A bank is said to be distressed when it is technically insolvent, implying that, the banks liability exceed its assets. At this stage the bank cannot meet its maturing obligation to its customers, shareholders and the rest of the economy as at when due. A clear example of this is the closure of 224 and 84 MFBs in Nigeria in 2010 and 2014 respectively by the apex bank-Central Bank of Nigeria, (www.cenbank.org).

Idama et al (2014) put it that, credit risk continues to be a threat to microfinance Bank sustainability. This paper therefore examines the causes of credit risks and made valuable recommendations that will help microfinance banks to reduce credit risks, avoid being distressed or bankrupt and post more profit.

Several authors have written on suitable lending methodologies, microfinance principles and practice and a lot more, yet portfolio at risks in microfinance banks has continue to be on the increase. This paper is therefore quite distinct as it gives greater insights into the causes of loan defaults in Microfinance Banks and how it can be best handled.

\section{Objectives Of The Study}

To identify major factors that lead to credit risk portfolio in microfinance banks and provide recommendations aimed at mitigating credit risks in microfinance banks.

\section{Review Of Literature}

Microfinance, according to Otero $(1999, \mathrm{p} .8)$ is "the provision of financial services to low-income poor and very poor self-employed people". These financial services according to Ledgerwood (1999) generally include savings and credit but can also include other financial services such as insurance and payment services. Schreiner and Colombet (2001, p.339) define microfinance as "the attempt to improve access to small deposits and small loans for poor households neglected by banks." Therefore, microfinance involves the provision of 
financial services such as savings, loans and insurance to poor people living in both urban and rural settings who are unable to obtain such services from the formal financial sector.

Microcredit and microfinance are often used interchangeably, but it is important to highlight the difference between them because both terms are often confused. Sinha (1998, p.2) states "microcredit refers to small loans, whereas microfinance is appropriate where NGOs and MFIs supplement the loans with other financial services (savings, insurance, etc.)". Therefore microcredit is a component of microfinance in that it involves providing credit to the poor, but microfinance also involves additional non-credit financial services such as savings, insurance, pensions and payment services (Okiocredit, 2005). Having defined what microfinance is, we look at the definition of loan default.

The terms loan default, credit risk, portfolio at risk and delinquency have similar meanings and most literatures use them interchangeably. Adedapo (2007), defined loan default as the inability of a borrower to fulfil his or her loan obligation as and when due. Credit institutions owe it as a duty to secure depositors' funds. Hence, credit agencies attempt to prevent loan delinquency and default because if the loan is not paid, the lender's capital is lost and the institution will no longer be sustainable. IDAMA, Asongo A.I., and Ngutor N.,(2014) argued that, credit risk is client's failure to meet the terms of a loan contract. An effective and sound credit risk is critical to the stability of microfinance Banks. Similarly, Agene (2011) defined credit risk portfolio as the deterioration of loan portfolio quality that results in loan losses and high delinquency management cost.

According to www.wikipeadia.com, default is failure to meet the legal obligations (or conditions) of a loan for example, when a home buyer fails to make a mortgage payment, or when a corporation or government fails to pay a bond which has reached maturity. A national or sovereign default is the failure or refusal of a government to repay its national debt. Default can be of two types: debt services default and technical default. Debt service default occurs when the borrower has not made a scheduled payment of interest or principal. Technical default occurs when an affirmative or a negative covenant is violated.

www.investopedia.com put it that loan default is a failure to promptly pay interest or principal when due. Default occurs when a debtor is unable to meet the legal obligation of debt repayment. Borrowers may default when they are unable to make the required payment or are unwilling to honor the debt.

According to Ledgerwood (2000), a delinquent loan becomes defaulted when the chance of recovery becomes minimal. Delinquent loans are loans that have an amount that has become due and not been received. Generally, loans that are in arrears, past due, and overdue have become due and have not been paid.

For microfinance Banks to exactly ascertain their default rate, portfolio at risk ration must be measured. Micro save (2000), defined portfolio at Risk ratio as a measure of the potential for future losses based on the current performance of the portfolio. It is the most widely accepted standard and ratio of portfolio performance in Microfinance.

Many researches have been done on credit risk of financial institutions. Recent work include that of Achal B., et al. (2008) who derived sharp asymptotic for two common risk measure: the portfolio loss distribution and expected shortfall. Others include work done by Glasserman and Li (2003) who developed large deviation asymptotic for the probability of large losses, and important-sampling simulation procedures for homogenous procedures for homogenous portfolio within the normal copula framework.

\section{Materials And Methods}

\subsection{Study Area:}

Yola is the administrative capital of Adamawa State of Nigeria. It is a twin settlement consisting of Jimeta -administrative and commercial center, and Yola Town - the traditional settlement. Yola is located on latitude $9^{\circ} 14^{\prime \prime} \mathrm{N}$ and longitude $12^{\circ} 28^{\prime} \mathrm{E}$. It has total land coverage of 662.47 square kilometers and a population of 395,871 persons (National Bureau of Statistics, 2006). Yola has a tropical climate marked by rainy and dry seasons. The maximum temperature can reach 40C particularly in April, while minimum temperature can be as low as $18{ }^{\circ} \mathrm{C}$ between December and January (Abdurrahman, 2013).

\subsection{Data Collection}

Questionnaires were administered to 169 customers and 20 staff of standard Microfinance Bank Limited, Yola, Nigeria which was the main source of data collection for the research work.

\subsection{Design of the Study}

This study employed the use of survey research method, due to the nature of the research, which involved practical issues. The questionnaires were designed to find the customers' and staff views on why loans are not paid back or paid late when collected, with reference to Standard Microfinance Bank Limited, Yola, Nigeria. The target population consisted of some randomly selected customers and staff of Standard Microfinance Bank Ltd. From the population of the study, one hundred and sixty nine (169) and twenty (20) 
respondent for customers and staff respectively were randomly selected and served with questionnaires accordingly.

\subsection{Method of Data Analysis}

The main tools for data analysis was Statistical Package for Social Sciences (SPSS) version 21. The software was used to obtain descriptive and inferential statistics such as tables, frequency and test of relation among variables using chi square.

\section{Results And Discussion}

The research revealed that $75 \%$ of the staff spent between 0 and 5 years with the Bank as at the time of this research. $25 \%$ of the staff spent more than 5 years with the Bank (see Table 1a). The research also revealed that majority (77.9\%) of the customers were banking with Standard Microfinance Bank for less than 5 years, as shown in Table 1b. There was an indication of high staff turnover and clients' dropouts. High staff turnover and clients dropouts are among the causes of poor loan repayment. This is because frequent changes of staff leads to customer dissatisfaction and eventual clients' dropout due to lack of necessary skills by the new employees. The chi square test results shown in Table 1c confirmed that the number of years the staff spent with Standard Microfinance Bank correlated highly (significant at $\mathrm{p}<0.05$ ) with the number of years the customers spent with the Bank.

Table $2 \mathrm{~b}$ of the survey revealed that $10.7 \%$ of SMFB's borrowers were never supervised on how the funds borrowed from the Bank was utilized. 17\% were supervised only once, $58.35 \%$ were supervised 2-5 times while $13.7 \%$ were supervised more than 5 times. Supervision of borrowers to ensure that funds borrowed from the Bank for economic activities are never diverted to other financial needs reduces the chances of loan default. Failure to pay attention to this will in no doubt result to default, most especially if the funds are put into noincome generating activities.

As shown in Table 3a, Twelve percent $(12.0 \%)$ of the respondents said they were never reminded to pay back their loans, $13.9 \%$ said they were reminded only once, $49.1 \%$ were reminded for $2-5$ times while $24.8 \%$ were reminded for more than 5 times. Most customers will not pay their loans willingly until when reminded repeatedly by the bank. Chi square results shown in Table $2 \mathrm{c}$ confirmed that loan repayment in microfinance bank depends on constant reminder of the clients $(p<0.05)$.

Majority of the respondents $(89.8 \%)$ indicated that they received some kind of training before receiving loans, $7.8 \%$ reported that they did not received any training before the loan was giving to them while $2.4 \%$ admitted that they received the training but could not understand what it was all about (see Table 4a). Training of clients on basic business principles empowers them with knowledge on utilization of the funds, which in turn would translate to higher income and timely loan repayment. However, chi square test results shown in Table $4 \mathrm{~b}$ revealed that loan repayment does not depend on training received before taking loan from the Bank $(p>0.05)$.

Table 5a confirmed that various penalties were meted out to some defaulters according to the survey. 42.2\% said their loan interest rate was increased, $6.2 \%$ were taken to police station, $22.4 \%$ were denied repeated loans. However, $27.3 \%$ said there was no penalty on them despite default. When there is no penalty for late or non- repayment of loans, it creates avenue for more defaults. The respondents that fell within this category will no doubt contribute more to the loan default rate of the Bank. It is also observed that there was no uniformity in dealing with defaulters. Some were punished while others were not punished. The Bank has to tighten its policy on loan default; this will create fears into the customers to pay back their loans on time.

On clients' level of indebtedness shown in Table 6a, the survey had revealed that majority (59.9\%) of the Standard Microfinance Bank (SMFB) customers were owing money from one source or the other before approaching the Bank for a credit facility. The findings revealed that in addition to the money collected from SMFB, $7.9 \%$ borrowed from money lenders in the market, $18.4 \%$ borrowed from their suppliers, $26.3 \%$ borrowed from friends while 7.2\% were owing other Microfinance Banks. Multiple borrowings or over indebtedness is the primary cause of loan default in Microfinance Banks. The chi square test result shown in Table $6 \mathrm{~b}$ revealed that the loan repayment rate correlated highly $(\mathrm{p}<0.05)$ with customers' multiples debts from various sources. Loan officers relied solely on customers' information in order to know whether clients have loans from other places or not, this of course will not give a correct picture as many customers tend to hide vital information that may disqualify them from getting the loan. The bank should therefore devise other means of checking customers' indebtedness like use of credit bureaus.

The survey result showed that $25 \%$ of the staff attended training only once since they joined the Bank, $25 \%$ attended training related to their jobs twice and 5\% did not attend any training at all as at the time of this research while $45 \%$ attended training more than two times (see Table 8 ). Staff training is the bedrock of success for any organization. Limited number of trainings attended by the staff of Standard Microfinance Bank (SMFB) was an indication that the staff may not have the necessary required knowledge for their jobs. There is no doubt that the problem of loan default may be as a result of lack of necessary skills by the staff. This was proven as 
$45 \%$ of the staff responded that one of their major challenges was locating customers' residential or business addresses when default occurred. This was a clear indication that "Know Your Customer (KYC)" principles were not followed as at the time of opening accounts for the clients. Furthermore, the chi square results in Table 10 revealed a significant difference $(\mathrm{p}<0.05)$ in the proportion of number of trainings attended by staff and their job performances.

Standard Microfinance Bank limited has a lending policy in place. The research however revealed the low level of compliance to the policy by the loan officers (see Table 11). Majority of the staff said their compliance to the Bank's lending policy was from $60 \%$ downward. Deviations from the lending guidelines of the bank are other reasons for high rate of default in the Bank. The management of the Bank should step up actions to ensuring that lending policies and guidelines are fully complied with by all staff.

Clients' selection plays a key role to loan repayment in the long run. A mistake done at this initial stage will be very difficult to correct. The survey proved that some loan officers bring customers to a group during group formation (see Table 12). This is not the best practice; the bank should use lead or existing clients to choose group members not the loan officer. This is to avoid Bank officials imposing clients on the group to borrow on their behalf or perhaps choose a wrong client. This also help prevent lack of misunderstanding among group members which often leads to loan default.

\section{Conclusion}

The finding of this study provides greater understanding into the many causes of loan defaults in Microfinance Banks. Majority of these causes were internal problems associated with the Banks' mode of operations which when properly addressed, microfinance banks will have a good loan portfolio, fulfil its primary role of poverty alleviation and remain sustainable. This research provide very enriching recommendations to help microfinance practitioners tackle loan default headlong. The study was limited to the causes of loan default in Microfinance Banks; we recommend further research on the assessment of Microfinance Banks performance in term of credit risk portfolio and to achieving international bench marks.

\section{Recommendations}

Based on the findings of the current research, the following recommendations are made for policy adoption:

i. Regular Credit risk assessment and analysis should be undertaken, preferably monthly or quarterly by the management of MFBs, as this is a continuous process rather than a once in a while exercise.

ii. Microfinance Banks should ensure industry standard in employment, ensuring that the best hands are engaged, and engage in training and retraining of staff for optimum performance.

iii. Microfinance Bank officials should personally visit the group clients, either in their shops or houses to ascertain that the group is genuinely formed and that all members are serious business people and not just members by name. This will also avoid customers giving fake addresses with the intention to run away with the Bank money.

iv. Loan officer should visit the borrower's business after disbursement and verify that the amount has been used as specified. Diversion of funds to other purpose other than what the money was actually borrowed for is a major cause of default. The Bank has to insist on this because sometimes the loan officer himself may be reluctant most especially if he has an interest in the loan.

v. If the installment remains unpaid at the close of daily business, the customer should immediately be reminded. SMS may be sent to mobile phones of defaulter, and in longer delays, phones calls should be made; finally the loan officer should raise the issue in the next group meeting and give a written reminder to the group. This will create consciousness among the group members that the Bank is monitoring them.

vi. Clients should choose group members themselves not the loan officer. This is to avoid Bank official imposing clients on the group to borrow on their behalf

vii. The management of SMFB should review its lending policies in line with industry best practices and also ensure strict compliance by all staff members.

Table 1a: Number of Years Staff Spent With the Bank

\begin{tabular}{|ll|l|l|l|}
\hline & Frequency & Percent & Cumulative Percent \\
\hline Valid & 15 & 75.0 & 75.0 \\
& $0-5$ years & 5 & 25.0 & 100.0 \\
& 6-10 years & 20 & 100.0 & \\
\hline Total & &
\end{tabular}


Table 1b: Number of Years Customers Spent With the Bank

\begin{tabular}{|ll|l|l|l|}
\hline & & Frequency & Valid Percent & Cumulative Percent \\
\hline Valid & Less than 1 year & 56 & 33.3 & 33.3 \\
& 1-4 years & 75 & 44.6 & 78.0 \\
& 5-10 years & 33 & 19.6 & 97.6 \\
& Above 10 years & 4 & 2.4 & 100.0 \\
& Total & 168 & 100.0 & \\
Missing & System & 1 & & \\
Total & 169 & & \\
\hline
\end{tabular}

Table 1c: Chi-Square Tests for Staff and Customers Years Spent With the Bank

\begin{tabular}{|l|l|l|l|}
\hline & Value & Df & Asymp. Sig. (2-sided) \\
\hline Pearson Chi-Square & $14.333^{\mathrm{a}}$ & 6 & .026 \\
Likelihood Ratio & 16.685 & 6 & .011 \\
Linear-by-Linear Association & 8.396 & 1 & .004 \\
N of Valid Cases & 168 & & \\
\hline
\end{tabular}

a. 7 cells $(58.3 \%)$ have expected count less than 5 . The minimum expected count is .12 .

Source: Survey Data, 2014

Table 2a: Loan Status of the Bank Customers

\begin{tabular}{|ll|l|l|l|}
\hline & Frequency & Percent & Cumulative Percent \\
\hline Valid & Fully repaid & 38 & 22.5 & 22.5 \\
& Repayment on Schedule & 42 & 24.9 & 47.3 \\
Repayment in arrears & 80 & 47.3 & 94.7 \\
I don't know my loan status now & 6 & 3.6 & 98.2 \\
I have finished but was told am still owing & 3 & 1.8 & 100.0 \\
Total & 169 & 100.0 & \\
\hline
\end{tabular}

Table 2b: Supervision of loan utilization

\begin{tabular}{|ll|l|l|l|}
\hline \multicolumn{2}{|c|}{} & Frequency & Valid Percent & Cumulative Percent \\
\hline Valid & I have never been supervised & 18 & 10.7 & 10.7 \\
& Only once & 29 & 17.3 & 28.0 \\
& $2-5$ times & 98 & 58.3 & 86.3 \\
& More than 5 times & 23 & 13.7 & 100.0 \\
& Total & 168 & 100.0 & \\
Missing & System & 1 & & \\
Total & 169 & & \\
\hline
\end{tabular}

Table 2c: Chi-Square Tests for Loan end use Supervision and Repayment Status

\begin{tabular}{|l|l|l|l|}
\hline & & & \\
& Value & df & Asymp. Sig. (2-sided) \\
\hline Pearson Chi-Square & $41.882^{\mathrm{a}}$ & 12 & .001 \\
Likelihood Ratio & 46.662 & 12 & .000 \\
Linear-by-Linear Association & 3.470 & 1 & .062 \\
N of Valid Cases & 168 & & \\
\hline
\end{tabular}

a. 10 cells $(50.0 \%)$ have expected count less than 5 . The minimum expected count is .32 .

Table 3a: Reminder for Non-payment

\begin{tabular}{|c|c|c|c|c|}
\hline & & Frequency & Valid Percent & Cumulative Percent \\
\hline \multirow[t]{5}{*}{ Valid } & I have never been reminded & 20 & 12.1 & 12.1 \\
\hline & Only once & 23 & 13.9 & 26.1 \\
\hline & $2-5$ times & 81 & 49.1 & 75.2 \\
\hline & More than 5 times & 41 & 24.8 & 100.0 \\
\hline & Total & 165 & 100.0 & \\
\hline $\begin{array}{l}\text { Missing } \\
\text { Total }\end{array}$ & System & $\begin{array}{l}4 \\
169\end{array}$ & & \\
\hline
\end{tabular}


Table 3b: Chi-Square Tests for Customer Reminder for Loan Repayment and their Loan Status

\begin{tabular}{|l|l|l|l|}
\hline & Value & Df & Asymp. Sig. (2-sided) \\
\hline Pearson Chi-Square & $53.275^{\mathrm{a}}$ & 12 & .000 \\
Likelihood Ratio & 56.651 & 12 & .000 \\
Linear-by-Linear Association & 8.257 & 1 & .004 \\
N of Valid Cases & 165 & & \\
\hline
\end{tabular}

a. 10 cells $(50.0 \%)$ have expected count less than 5 . The minimum expected count is .36 .

Table 4a: Loan Pre-disbursement Training

What kind of training was giving to you by Standard Microfinance Bank's official before giving you the loan?

\begin{tabular}{|ll|l|l|l|}
\hline & Frequency & Valid Percent & Cumulative Percent \\
\hline Valid & How to use the loan collected & 84 & 50.3 & 50.3 \\
& How to manage my business & 66 & 39.5 & 89.8 \\
& There was no training & 13 & 7.8 & 97.6 \\
& There was training but I did not understand it. & 4 & 2.4 & 100.0 \\
& Total & 167 & 100.0 & \\
Missing & System & 2 & & \\
Total & & 169 & & \\
\hline
\end{tabular}

Table 4b: Chi-Square Tests for Loan Pre-disbursement Training and Repayment Status

\begin{tabular}{|c|c|c|c|}
\hline & Value & Df & Asymp. Sig. (2-sided) \\
\hline Pearson Chi-Square & $18.976^{\mathrm{a}}$ & 12 & .089 \\
\hline Likelihood Ratio & 18.181 & 12 & .110 \\
\hline Linear-by-Linear Association & 3.296 & 1 & .069 \\
\hline $\mathrm{N}$ of Valid Cases & 167 & & \\
\hline
\end{tabular}

a. 13 cells $(65.0 \%)$ have expected count less than 5 . The minimum expected count is .07 .

Source: Survey Data, 2014

Table 5a: Penalty for Loan Default

What penalty did Standard Microfinance Bank gave you for not paying your loan on time?

\begin{tabular}{|ll|l|l|l|}
\hline & Frequency & Valid Percent & Cumulative Percent \\
\hline Valid & Interest rate was increased & 68 & 42.2 & 42.2 \\
& I was taken to police station & 10 & 6.2 & 48.4 \\
& There was no penalty & 44 & 27.3 & 75.8 \\
& I was told no more loan for me again & 36 & 22.4 & 98.1 \\
& my business was sold off by the bank & 3 & 1.9 & 100.0 \\
& Total & 161 & 100.0 & \\
Missing & System & 8 & & \\
Total & & 169 & & \\
\hline
\end{tabular}

Table 5b: Chi-Square Tests for Penalty on Loan Default and Repayment Status

\begin{tabular}{|c|c|c|c|}
\hline & Value & $\mathrm{Df}$ & Asymp. Sig. (2-sided) \\
\hline $\begin{array}{l}\text { Pearson Chi-Square } \\
\text { Likelihood Ratio } \\
\text { Linear-by-Linear Association } \\
\text { N of Valid Cases }\end{array}$ & $\begin{array}{l}39.660^{\mathrm{a}} \\
33.024 \\
594 \\
161\end{array}$ & $\begin{array}{l}16 \\
16 \\
1\end{array}$ & $\begin{array}{l}.001 \\
.007 \\
.441\end{array}$ \\
\hline
\end{tabular}

a. 16 cells (64.0\%) have expected count less than 5 . The minimum expected count is .06 .

Source: Survey Data, 2014 
Table 6a: Customers' Over Indebtedness

At the time of applying for these loan(s), who did you owe?

\begin{tabular}{|ll|l|l|l|}
\hline & Frequency & Valid Percent & Cumulative Percent \\
\hline Valid & Money lender in the market & 12 & 7.9 & 7.9 \\
& My supplier & 28 & 18.4 & 26.3 \\
& My Friends & 40 & 26.3 & 52.6 \\
& Other microfinance Banks. & 11 & 7.2 & 59.9 \\
& no body & 61 & 40.1 & 100.0 \\
& Total & 152 & 100.0 & \\
Missing & System & 17 & & \\
Total & & 169 & & \\
\hline
\end{tabular}

Table 6b: Chi-Square Tests for Clients Level of Indebtedness and Loan Repayment Status

\begin{tabular}{|l|l|l|l|}
\hline & Value & df & Asymp. Sig. (2-sided) \\
\hline Pearson Chi-Square & $39.660^{\mathrm{a}}$ & 16 & .001 \\
Likelihood Ratio & 33.024 & 16 & .007 \\
Linear-by-Linear Association & .594 & 1 & .441 \\
N of Valid Cases & 161 & & \\
\hline
\end{tabular}

a. 16 cells $(64.0 \%)$ have expected count less than 5 . The minimum expected count is .06 .

Table 7: Staff Checks on Customers Multiple Borrowings

Do you normally do a check on your borrowers whether they have a loan from another financial institution before coming to your bank?

\begin{tabular}{|ll|l|l|l|}
\hline & Frequency & Valid Percent & Cumulative \\
\hline Percent
\end{tabular}

Source: Survey Data, 2014

Table 8: Number of Trainings Attended by Staff

How much training on lending have you attended since you joined Standard microfinance Bank?

\begin{tabular}{|ll|l|l|l|}
\hline & Frequency & Valid Percent & Cumulative Percent \\
\hline Valid & Once & 5 & 25.0 & 25.0 \\
& Twice & 5 & 25.0 & 50.0 \\
& More than two & 9 & 45.0 & 95.0 \\
& I have not attended any & 1 & 5.0 & 100.0 \\
Total & 20 & 100.0 & \\
\hline
\end{tabular}

Table 9: What Has Been Your Major Challenge Locating the Customer When there is Default?

\begin{tabular}{|l|l|l|l|l|}
\hline & Frequency & Valid Percent & Cumulative Percent \\
\hline Valid & Incomplete addresses & 9 & 45.0 & 45.0 \\
& Relocation & 6 & 30.0 & 75.0 \\
Customers not known with the name used & 2 & 10.0 & 85.0 \\
No passport photographs & 3 & 15.0 & 100.0 \\
Total & 20 & 100.0 & \\
\hline
\end{tabular}


Table 10: Chi-Square Tests For Staff Training Level And Job Performance

\begin{tabular}{|l|l|l|l|}
\hline & Value & df & Asymp. Sig. (2-sided) \\
\hline Pearson Chi-Square & $19.556^{\mathrm{a}}$ & 9 & .021 \\
Likelihood Ratio & 16.997 & 9 & .049 \\
Linear-by-Linear Association & 2.723 & 1 & .099 \\
N of Valid Cases & 20 & & \\
\hline
\end{tabular}

a. 16 cells $(100.0 \%)$ have expected count less than 5 . The minimum expected count is .10 .

Source: Survey Data, 2014

Table 11: Level of Compliance to SMFB's Lending Policies What is your level of compliance to the credit policy of the Bank?

\begin{tabular}{|ll|l|l|l|}
\hline & Frequency & Valid Percent & Cumulative Percent \\
\hline Valid & $70 \%$ & 9 & 47.4 & 47.4 \\
& $60 \%$ & 5 & 26.3 & 73.7 \\
& $50 \%$ & 3 & 15.8 & 89.5 \\
& Below 50\% & 2 & 10.5 & 100.0 \\
Total & 19 & 100.0 & \\
Missing & System & 1 & & \\
\hline Total & 20 & & \\
\hline
\end{tabular}

Source: Survey Data, 2014

Table 12: Clients selection For Group Lending

How do you select your group clients?

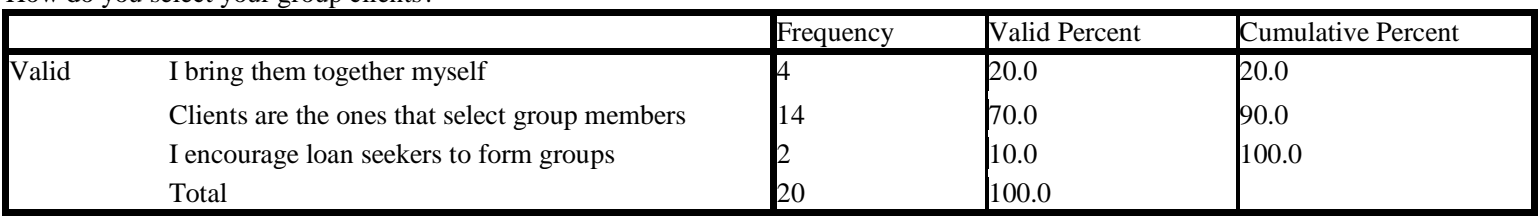

Source: Survey Data, 2014

\section{References}

[1]. Abdurrahman Belel, Ismaila: Evaluating Land Use Change in Rapidly Urbanizing Nigeria: Case Study of Yola Adamawa StateGeo Informatics for City Transformation, 2013, 21-23

[2]. Achal, Bassamboo., Sandeep Juneja and Assaf Zeevi: Iportfolio Credit Risk with External Dependence: Asymptotic Analysis and Efficient Simulation, Operations Research, Vol. 56, No.3, May-June 2008, pp.593-606.

[3]. Adamu Idama, Asongo A.I \& Nyor N: Credit Risk Management in Microfinance Banks: Conceptual and Practical Insights, Universal Journal of Applied Sciences 2(6): 2014, 111-119.

[4]. Adedapo K.D, Analysis of Default Risk of Agricultural Loan by some Selected Commercial Banks in Osogbo, Osun State, Nigeria: International Journal of Applied Agriculture and Apiculture Research: IJAAAR4 (1\&2), 2007, 24-29.

[5]. Agene, C.E. Microfinance Banking, principles and practice. (Gene publications, Abuja, 2011)

[6]. Central Bank of Nigeria, Microfinance Policy. Regulatory and Supervisory Framework for Nigeria, (2011).

[7]. Glasserman, P., J. Lai, Importance Sampling for Portfolio Credit Risk. Management Science 51, 2003, $1643-1656$.

[8]. Ledgerwood, J. (1999). Microfinance Handbook: An Institutional and Financial Perspective, Washington, D.C.: The World Bank.

[9]. Market Led Solution for Financial Services (MicroSave): Loan Portfolio Audit Tool for MFIs, Nairobi, 2003

[10]. National Bureau of Statistics (2006) Annual Abstract of Statistics 2006. Federal Republic of Nigeria

[11]. Nnanna, O.J. (2003). Today’s Banking Risks and Current Regulatory Framework. CBN Bullion; July/September, Vol. 27, No.3. 30

[12]. OkioCredit (2005) Small Loans Great Change: building a future with Microfinance. In: International Microfinance Symposium, Bonn

[13]. Otoro (2007), Perceptions of the Impact of Microfinance on Livelihood Security, Kimmage Development Studies Centre, Holy Ghost College, Kimmage Manor, Whitehall Road, Dublin 12, Ireland

[14]. Schreiner, M.; and H.H. Colombet. (2001) "From Urban to Rural: Lessons for Microfinance from Argentina", Development Policy Review, Vol. 19, No. 3, pp. 339-354. Versión en español: "Las Microfinanzas en la Zona Rural de Argentina".

[15]. Sinha, Dipendra, 1998. Economic growth and government expenditure in China, MPRA Paper 18347, University Library of Munich, Germany.

[16]. www.cenbankng.org/microfinancebanks

[17]. http://www.investopedia.com/loandefault

[18]. http://www.wikipedia.com/defaultloans 